\title{
Enabling Learners to Become Critical Cosmopolitan Citizens
}

\author{
Taciana de Lira e Silva \\ University of Ottawa, Canada
}

\begin{abstract}
This discourse analysis is part of a research topic idea in the field of citizenship education. Three Ontario curriculum documents were chosen for an overview: The Social Studies Ontario Curriculum Grades 1 - 8 [15], the Canadian and World Studies Ontario Curriculum Grades 9 - 10 [15], which addresses civic education, and the English as a Second Language (ESL) and English Literacy Development (ELD) Grades 9 - 12 [17] that prepares newcomers to improve their English proficiency. The analysis confirmed that the discourse used by the Social Studies curriculum and the Canadian and World Studies document aimed to develop student's 'understanding' of the global world rather than prepare them to act for the betterment of the planet. In addition, the ESL and ELD curriculum document does not address citizenship education but focuses mainly on the need to prepare newcomers to participate in the job market. This exploratory case study will inquire how educators and Ontario's native and newcomer students perceive citizenship through a Critical Cosmopolitan Citizenship Education (CCCE) approach while investigating ways in which CCCE encourages educators and students to respect Human-Rights (HR) and become active citizens who fight for peace and sustainability in a globalized world where racial, ethnic, cultural and language diversity, often cre.ates problems between the selfproclaimed natives and the newcomers. Critical Cosmopolitan citizenship education is a transformational approach that empowers learners to become global citizens who are involved in the local, national and global communities and envision building a better world.
\end{abstract}

\section{Introduction}

The second half of 20th century was marked by Globalization and the cognizance of environmental challenges that could lead to the extinction of life on Earth. The Geological Society [27] defends that humans have engendered irreversible changes in Earth's chemical, physical and biological systems and claims we have entered a new geological era, the Anthropocene, that could be very destructive to all species on the planet. In addition, Globalization has created human displacement and new financial, cultural, racial, and social relationships in all walks of life [4]. Therefore, education in the $21^{\text {st }}$ century must become a reflection of our new reality.

CCCE is education for peace, human rights and sustainability [21]. In the 21 st century educators and learners need to reflect upon global challenges and prepare themselves to accept diversity and improve environment and human life while aiming to build a better world. "Il faut donc adopter une perspective holistique de la qualité de vie" [12]. The author explains that if humans of all age, especially children, stay in constant contact with nature they create a relationship of respect towards the environment, which is essential for a better quality of life not only in the personal ambit but also globally. Sommerville [25] states that adults have a moral obligation to create a connection between children and nature. Respect for the environment must be nurtured in all ages and through all spheres of life.

Students need to become critical citizens who reflect on how their own communities, address human rights and defend their own and the rights of those who encounter injustice, discrimination and exclusion [22]. Cosmopolitan education is citizenship education that aims to help learners become citizens of the world without giving up their feeling of allegiance to their country and culture, which according to Nussbaum [13] and Appiah [1] foster understanding of the diverse cultural approaches in the global society.

This study results from a gap in the literature that has not shown studies in Canada that address how Canadian and Newcomer students perceive citizenship education through a cosmopolitan education approach.

\section{The Ontario Curriculum and the UN Declaration of Human Rights Education and Training}

It is necessary to inquire whether the Ontario Curriculum addresses CCCE. A brief review of three documents showed little reference to building active citizens who work toward creating a more inclusive, equal and sustainable world. The Social Studies Ontario Curriculum Grades 1 - 8 [15], emphasizes a wholesome understanding of diversity, as well as the interconnection between the natural environment and humans. However, it does not emphasize the 
development of active citizenship aiming to develop relationships of equality with the members of diverse communities and respect for the environment. In this framework, the students portray a passive role in society.

The vision of the Canadian and World Studies The Ontario Curriculum Grades 9 - 10 [16] is to "enable students to become responsible, active citizens within the diverse communities to which they belong. As well as becoming critically thoughtful and informed citizens who value an inclusive society." (p.6). This document also focuses on civics "a branch of politics that explores the rights and responsibilities of citizens, ... and ways in which citizens can act for the common good within communities at the local, national, and/or global level" (p.12). In addition, it states that the responsibilities of citizenship include the "protection and stewardship of the global commons, such as air and water, on a local, national, and global scale." (p. 46). Although the curriculum has changed its discourse and talks about acting for the common good, its focus is on immediate concerns, such as air and water that are already affecting the planet. It does not voice the idea of improving human life in other sectors like human rights, health, finance, and education.

The Ontario Curriculum, Grades 9 to 12, English as a Second Language and English Literacy Development [17] states that the "culminating vision of successful English language learners identifies the language skills and capabilities required for success in Ontario's education system and for full participation in Canadian society." (p.4) This document emphasizes the need to prepare the newcomers to participate in the job market but overlooks the acknowledgement of the existence of diverse cultures in this country. A hegemonic view of society that indirectly encourages newcomers to assimilate the hegemonic culture and adapt to their new reality.

Although the Ontario ESL and ELD Curriculum Grades 9 - 12 [17] does not mention environment or sustainable education, the Ontario Curriculum Canadian and World Studies, Grades 9 - 10 (2018) has a policy for environment called "Acting Today, Shaping Tomorrow: A Policy Framework for Environmental Education in Ontario Schools" (p.46). This policy acknowledges the need of all Ontario students to become environmentally responsible. The framework has three goals: promote environmental learning, engage students to become environmental stewardship, and have individuals and organizations within the education system to encourage teachers and students continue their journeys of environmental stewards. Unfortunately, the document does not mention that students need to be involved in activities that promote sustainability but suggests that students are encouraged to "explore a range of environmental issues [related to] Canadian resource management, population growth and urban sprawl, and the impact of human activity on the natural environment" (p.46).
This discourse indicates that students should learn about how global issues affect Canada, instead of widening the focus of education to a real global environment education.

The brief overview of the three documents displayed a lack of inclusion of education for activism and empowerment to build a better world, an activism that begins with self and includes the various levels of human and environment interaction. The Declaration of Human Rights Education and Training created by the UN [28], aims to promote universal respect and freedom. The document shares that there are three was to approach human right education: education about rights (awareness of the principles of human rights); education through rights (students learn about their rights); and education for rights (that empowers the learner to use their rights to help others). All forms of education are valid and important; however, education for rights motivate students to try to change the world. The Ontario Curriculum documents focus on education about rights and through rights but lacks to empower the students to learn for the rights of self and others.

Through the CCCE teacher and students work together aiming to understand injustices, and to find ways of changing the status quo. For CCCE to happen, teachers and students need to understand principles of Critical pedagogy, sustainability and Cosmopolitan education.

\section{Critical Pedagogy}

John Dewey is considered the father of the Progressive Education, un approach that claims teaching should engage and broaden the learner's experience. In addition, the author believed that a democratic society "must have a type of education which gives individuals a personal interest in social relationships and control, and the habits of mind which secure social changes without introducing disorder." [5].

Many educational philosophers developed theories that view education as the ground-breaking institution for social reforms. Freire is considered the educational philosopher who most influenced the development of critical pedagogy. In his seminal work Pedagogy of the Oppressed [7] he explains that there are two types of human beings, oppressed and oppressor, and social changes can happen in a positive and constructive way when the oppressed is empowered. Unfortunately, according to Freire [7], the educational system treats the learners as empty banks, passive learners, and the teacher, is the owner of knowledge who fills up the banks with knowledge. In this relationship, the teacher is the subject, and the students, simple objects. Freire [7] stated that only through praxis a process of "reflection and action directed at the structures to be transformed." (p.126) 
the oppressed can become critically aware of their condition and fight for their freedom.

Foucault [6] talks about power as productive, albeit ambiguous, and as having the potential of spreading out and reaching the community at large. The author explains "it produces things..., forms of knowledge, produces discourse. It needs to be thought of as productive network which runs through the whole social body." (p.119). Foucault did not state that power was good or bad, but that it has the ability to produce top-down and bottom-up changes in society. Critical pedagogy fosters a relationship of cobuilders of knowledge between teacher and student. It empowers the learner to think critically and to try to fight injustices against humans and against the environment, promoting relations of equality between the human and the more than human, and trying to change the dichotomous worldview that sees the environment as an object to serve humanity.

\section{CCCE}

Education is not a neutral process; it is either used to influence learners to accept the structure of the system, or to empower them to be critical and to transform the world. To build a better world, Curriculum expectations should include human rights, peace and sustainability Education. In this framework, learning happens through critical thinking and fosters curiosity, openness, engagement and action.

There is a large body of work that identifies with cosmopolitan citizenship [5], [9], [8], [10], [3], [11], [20], [18], [19], [2]. Osler and Starkey [18] argue that cosmopolitan citizenship is a status, a feeling, and a practice at all levels. They explain that "students are holders of inalienable human rights, rather than their presumed status as citizens" (p.2).

ESL students often struggle between accepting a Canadian identity and dismissing their heritage; many can feel homeless in their new home. A critical cosmopolitan education approach empowers students to develop thoughtful and positive relationships with their cultural communities, nation-states, and the global community, and provides the skills needed to promote democracy at the national and global level. Through the critical cosmopolitan education framework educators empower learners to transform the world. As [14] posits, according to one's understanding of citizenship, they can think of themselves as members of a homogeneous group or as members of various groups that are made of people from all walks of life all of whom deserve to be respected and understood.

Although most people still experience citizenship for the first time through school, in their local community, globalization exists de facto and young citizens must become aware that we live in a global civilization with common global problems that need global cooperation to be solved. Otherwise, students won't learn to see humanity through the lenses of equality or nature as a common place for all. CCCE values and promotes individual identities. In this framework, students are not obligated to restrict or extend their horizons, but they learn that a citizen of the world works hard advocating for peace, human rights and sustainability.

Opposition to the ideal of cosmopolitanism abounds. Pheng Cheah [23] explains that Marx saw cosmopolitanism as a way of exploiting the world through a global way of production and the establishment of international commerce. "The bourgeoisie has through its exploitation of the world market given a cosmopolitan character to production and consumption in every country..... [as well as] [t]he intellectual creations of individual nations" (Marx, 1848,1973 , p. 71), which according to the author, had been replaced by a global culture.

The father of modern China, Sun Yat-sen [24] also opposed to an independent cosmopolitanism. He insisted that a nation needs to establish a strong nationalism and that "[w]e must understand that cosmopolitanism grows out of nationalism. If nationalism cannot become strong, cosmopolitanism certainly cannot prosper" (p. 89).

\section{Methodology}

Action research will be the methodological approach of this study. I seek to understand learners' reactions as they interact with various systems and learn through a critical cosmopolitan education approach. In addition, Stringer [26] suggests that action research is an important approach when seeking ways to enhance teachers' professional learning and improve students' learning experiences. This study will inquire ways in which Canadian learners, and newcomers in the second language classroom, will become aware of cultural diversity and environmental issues, and how they will become active citizens willing to construe a better world. Data collection methods for this research will be: critical analysis of three Ontario Curriculum documents, teacher and student pre and post-task surveys, student blog or journal, students' sample work, Skype interview with teachers, and video conference with students.

\section{Ethical Issues}

In addition to having the approval of the University of Ottawa Ethics Board and of the School Board Ethics Committee, the participants' signatures of the consent form, ethical issues, such as respect for anonymity and confidentiality, and avoidance of deceptive practices are the researcher's concerns. To ensure anonymity and confidentiality, names of participants and of research sites will be replaced by pseudonyms, and a password-protected online private 
blog will be used to communicate with students and teachers. To keep veracity of context, the transcripts will be presented to the participants for review.

\section{Conclusion}

This discourse analysis was an essential step for the suggested future research in order to find out whether and how the Ontario ministry of Education addressed citizenship education in the curriculum, to be able to design the study. Citizenship education when shifted from a nation-state focus to a cosmopolitan approach might offer ways of solving global issues by ordinary citizens, instead of leaving the job for the politicians and stakeholders who mainly focus on local interests instead of the global wellbeing. Education encompasses all professions; if learners are empowered to make a change, they will be able to transform the world into a better place to live.

\section{References}

[1] Appiah, K. A. (2006) Cosmopolitanism: Ethics in a World of Strangers (New York: Norton)

[2] Banks, J. A. (2008). Diversity, Group Identity, and Citizenship Education in a Global Age. Educational Researcher, 37(3), 129-139.

[3] Beck, U. (2000). What is Globalization? Cambridge: Polity Press.

[4] Beck, U. \& Sznaider, N. (2006). Unpacking cosmopolitanism for the social sciences: a research agenda. The British Journal of Sociology, 57 (1), 1-23.

[5] Dewey, J. (2004). Democracy and education. Courier Corporation.

[6] Foucault, M., \& Gordon, C. (1980). Power/knowledge: selected interviews and other writings, 1972-1977 (1st American ed). New York: Pantheon Books.

[7] Freire, P. (1972). The pedagogy of the oppressed. New York: The Seabury Press.

[8] Habermas, J. (1996). Between facts and norms: Contributions to a discourse theory of law and democracy. Cambridge: Polity Press.

[9] Held, D. (1995) Democracy and the new international order. In D. Archibugi and D. Held (Eds.) Cosmopolitan democracy: An agenda for a new world order (pp. 96-120). Cambridge: Polity Press.

[10] Hutchings, K. \& Dannruether, R. (Eds.) (1999). Cosmopolitan Citizenship. Basingstoke, UK: Macmillan.

[11] Kaldor, M. (2003). American power: from 'compellance' to cosmopolitanism? International Affairs, 79(1), 1-22.
[12] Leblanc, Raymond (2018). La qualité de vie pour tous. Unpublished manuscript, Department of Education, University of Ottawa.

[13] Nussbaum, M. (2002). Patriotism and cosmopolitanism. In for love of country, ed. J. Cohen, 2-17. Boston: Beacon Press.

[14] Nussbaum, M. (2006). Education and Democratic Citizenship: Capabilities and Quality Education. Journal of Human Development, 7(3), 385-395.https://doi.org/10.108 0/14649880600815974

[15] Ministry of Education (2013). The Ontario curriculum grade 1 to 6 social studies and history grade 7 and 8 . Retrieved from http://www.edu.gov.on.ca/eng /curriculum/ elementary/sshg18curr2013.pdf

[16] Ministry of Education (2013). The Ontario curriculum grades 9 and 10: Canadian and world studies geography • history - civics (politics). Retrieved from http://www.e du.gov.on.ca/eng/curriculum/secondary/canworld910curr2 013.pdf

[17] Ministry of Education (2007). The Ontario curriculum , Grades 9 to 12: English as a second language and Engli sh literacy development. Retrieved from http://www.edu.g ov.on.ca/eng/curriculum/secondary/es1912currb.pdf

[18] Osler, A. \& Starkey, H. (2005). Changing citizenship: Democracy and inclusion in education. Maidenhead, UK: Open University Press.

[19] Osler, A. \& Starkey, H. (2003). Learning for cosmopolitan citizenship: Theoretical debates and young people's experiences. Educational Review, 55(3), 243-254.

[20] Osler, A. \& Vincent, K. (2002). Citizenship and the Challenge of Global Education. Stokeon-Trent, UK: Trentham.

[21] Osler, A. (2011). Teacher interpretations of citizenship education: National identity, cosmopolitan ideals, and political realities. Journal of Curriculum Studies, 43(1), 124. https://doi.org/10.1080/0022027 2.2010.503245

[22] Osler, A (2015). Human Rights Education, Postcolonial Scholarship, and Action for Social Justice. Theory and Research in Social Education, 43,(2), 244 274.

[23] Pheng, C. (1998). Cosmopolitics, thinking and feeling beyond the nation. Pheng, C. \& Bruce, R. (Eds.). Cultural Politics, 14. Minneapolis, London: University of Minneapolis.

[24] Sun Yat-sen (1927). San Min Chu I [The three principles of the people]. F. Price, Trans.). Shanghai: China Committee Institute of Pacific Relations.

[25] Somerville, M. (2006). The Ethical Imagination (Journeys of the Human Spirit). Toronto, Ontario: House of Anansi Press.

[26] Stringer, E. (2008). Action research in education. Merrill Prentice Hall: Pearson Education. 
International Journal for Cross-Disciplinary Subjects in Education (IJCDSE), Volume 10, Issue 1, March 2019

[27] The Geological Society (2005). Anthropocene. Retrieved from https://www.geolsoc.org.uk/anthropocene

[28] United Nations. (2011). United Nations Declaration on Human Rights Education and Training Retrieved from http://www.ohchr.org/EN/Issues/Education/Training / Com pilation /Pages/United Nations D United Nations Declarati ononHumanRightsEducat(2011).aspx 